\title{
PENGARUH VOLUME PENJUALAN, BIAYA PRODUKSI, DAN PAJAK PENGHASILAN TERHADAP LABA BERSIH DI BURSA EFEK INDONESIA
}

\author{
Eko Purwanto \\ Universitas Informatika dan Bisnis Indonesia (UNIBI) Bandung, Indonesia \\ ekopurwanto@unibi.ac.id \\ https://doi.org/10.46367/iqtishaduna.v10i2.422
}

Received: Oct 28, 2021 Revised: Nov 24, 2021 Accepted: Des 01, 2021 Published: Des 17, 2021

\begin{abstract}
Sales volume refers to the income from the company's top operating results, and production costs are all costs related to the production carried out by the company, while income tax is the company's obligation to the state, which is binding. The purpose of the study was to examine the effect of sales volume, production costs, and income tax on the company's net income. This research uses the causality method with quantitative data and purposive sampling technique. The research population is all companies in the food and beverage industry sector on the Indonesia Stock Exchange from 2014 to 2020. The sample of this research is 12 companies with 84 financial statements. Data analysis used a regression model. The results of the study indicate that income tax affects the company's net profit. Meanwhile, sales volume and production costs do not affect the company's net profit. This research can be a reference for investors in choosing companies in the food and beverage sector.
\end{abstract}

Keywords: Net Profit, Sales Volume, Production Cost, Income Tax.

\begin{abstract}
ABSTRAK
Volume penjualan merujuk pada pendapatan dari hasil utama operasi perusahaan, biaya produksi adalah semua biaya terkait dengan produksi yang dilakukan perusahaan, sedangkan pajak penghasilan adalah kewajiban perusahaan kepada negara bersifat mengikat. Tujuan penelitian adalah untuk menguji pengaruh volume penjualan, biaya produksi, dan pajak penghasilan terhadap laba bersih perusahaan. Penelitian menggunakan metode kausalitas dengan data kuantitatif dan teknik purposive sampling. Populasi penelitian adalah seluruh perusahaan sektor industri makanan dan minuman di Bursa Efek Indonesia periode 2014 sampai dengan tahun 2020. Sampel penelitian ini adalah 12 perusahaan dengan 84 laporan keuangan. Analisis data menggunakan model regresi. Hasil penelitian menunjukkan bahwa pajak penghasilan berpengaruh terjadap laba bersih perusahaan. Sedangkan volume penjualan dan biaya produksi tidak berpengaruh terhadap laba bersih perusahaan. Penelitian ini dapat menjadi referensi bagi investor dalam memilih perusahaan pada sektor makanan dan minuman.
\end{abstract}

Kata Kunci: Laba Bersih, Volume Penjualan, Biaya Produksi, Pajak Penghasilan. 


\section{PENDAHULUAN}

Laba bersih merupakan keuntungan yang didapat setelah dikurangi harga pokok dan berbagai pajak/beban, maka tinggi rendahnya laba bersih dipengaruhi oleh tinggi rendahnya penjualan dan beban. Penjualan merupakan suatu kegiatan yang terpadu untuk mengembangkan rencana-rencana strategis yang diarahkan pada usaha pemuasan kebutuhan dan keinginan pembeli, guna mendapatkan penjualan yang menghasilkan laba. Laba bersih yang tinggi bukan ukuran yang mutlak untuk mengukur baik atau tidaknya sebuah entitas dalam menjalankan usahanya. Setidaknya laba digunakan sebagai tolok ukur prestasi bagi sebagian besar perusahaan.

Terdapat dua faktor penentu laba yaitu pendapatan dan beban (Ghozali and Cahariri 2014, 375). Apabila pendapatan lebih besar dari pada beban maka akan diperoleh laba. Sehingga jika pendapatan setiap tahunnya semakin meningkat sementara beban operasionalnya turun maka secara otomatis akan diiringi oleh kenaikan laba. Pendapatan yang ada merujuk pada penjualan sebagai pendapatan utama perusahaan. Nominal penjualan merupakan akumulasi setiap unit yang terjual dalam periode tertentu. Sedangkan beban terdiri dari dua kriteria yaitu beban komersial dan biaya produksi (Mulyadi 2015). Biaya produksi merupakan segala sesuatu berkaitan dengan proses perubahan input jadi output. Selain pendapatan dan beban, terdapat laba bersih, dimana laba dikurangi pajak penghasilan (Islahuzzaman 2012). Sedangkan pajak berperan dalam penentuan tinggi atau rendahnya laba suatu perusahaan. Penelitian yang dilakukan Firmansyah (2019) mengungkapkan bahwa ada faktor yang mempengaruhi laba bersih, diantaranya adalah metode akuntansi yang digunakan, faktor estimasi laporan keuangan dan kinerja keuangan perusahaan secara umum. Namun penelitian ini mengkhususkan perusahaan kedalam satu sektor saja, yaitu sektor makanan dan minuman.

Penelitian ini bertujuan untuk menguji pengaruh volume penjualan, biaya produksi, dan pajak penghasilan terhadap laba bersih yang ada di perusahaan sektor makanan dan minuman yang terdaftar di Bursa Efek Indonesia periode 2014 sampai 2020. Pemilihan sub sektor makanan dan minuman didasarkan data bahwa perusahaan sektor makanan dan minuman adalah sektor andalan yang dimiliki oleh Indonesia. Dengan kata lain, terdapat kekuatan dari sektor makanan untuk bertahan dan memperoleh laba.

Hasil penelitian yang sudah ada menunjukkan hasil yang beragam antara yang satu dengan yang lainnya. Penelitian ini kembali mengangkat topik yang sama dengan tujuan memperoleh hasil yang general secara khusus untuk perusahaan sub sektor makanan dan minuman. Penelitian ini mengisyaratkan bahwa akan terdapat pengaruh untuk setiap variabelnya dikarenakan secara teoritis keilmuan terdapat hubungan saling mempengaruhi untuk keempat variabel yang ada.

\section{TELAAH LITERATUR}

Laba bersih merupakan laba yang telah dikurangi biaya-biaya yang merupakan beban perusahaan dalam suatu periode tertentu termasuk pajak (Kasmir 2011, 303). Beberapa faktor menjadi penentu laba diantaranya adalah 
biaya, harga jual dan volume penjualan (Mulyadi 2014, 303). Penelitian mengenai volume penjualan sudah pernah dilakukan oleh Puspitasari (2017); Fitrasani (2019); Alam (2020); Lisna and Hambali (2020) menunjukkan hasil volume penjualan berpengaruh terhadap laba bersih, sehingga hipotesis pertama dapat dirumuskan:

$\mathrm{H}_{1}$ : volume penjualan berpengaruh terhadap laba bersih.

Biaya merupakan pengorbanan sumber ekonomi yang diukur dalam satuan uang, yang telah terjadi atau yang kemungkinan akan terjadi untuk tujuan tertentu (Mulyadi 2015, 8). Biaya terdiri dari dua jenis, yaitu biaya produksi dan biaya operasional. Biaya produksi adalah biaya terkait dengan pembentukan produk dari awal sampai dengan produk tersebut jadi. Biaya produksi meliputi biaya bahan baku, biaya tenaga kerja langsung, dan biaya overhead pabrik. Sedangkan biaya operasional meliputi biaya lainnya seperti biaya penjualan dan biaya adminstrasi dan umum (Mulyadi 2015, 8). Penelitian yang berhubungan dengan biaya produksi sudah pernah dilakukan oleh Diana, Novia, Sagala, Steven, and Djokri (2020) menyatakan bahwa biaya produksi berpengaruh terhadap laba perusahaan. Kemudian penelitian yang dilakukan oleh Suwarni (2018); Jawad (2018); Izmi (2019); Ambarwati, and Kusnadianti (2021) menunjukkan hasil biaya produksi berpengaruh terhadap laba bersih, sehingga hipotesis kedua dapat dirumuskan:

$\mathrm{H}_{2}$ : biaya produksi berpengaruh terhadap laba bersih.

Pajak merupakan iuran yang dibayarkan oleh rakyat kepada negara yang masuk dalam kas negara yang melaksanakan pada undang-undang serta pelaksanaannya dapat dipaksakan tanpa adanya balas jasa. Iuran tersebut digunakan oleh negara untuk melakukan pembayaran atas kepentingan umum (Mardiasmo 2016, 3). Penelitian mengenai pajak sudah pernah dilakukan oleh Nur, Pitriani, Haryanti, Nur C., Ardiansyah, and Suripto (2019); Handayani (2017); Purdiansyah and Nurasik (2018); Wahyuni (2019) menyatakan bahwa pajak berpengaruh terhadap laba bersih perusahaan, sehingga hipotesis ketiga dapat dirumuskan:

$\mathrm{H}_{3}$ : pajak berpengaruh terhadap laba bersih.

\section{METODE PENELITIAN}

Metode penelitian yang digunakan adalah kausalitas. Metode kausalitas adalah metode yang digunakan untuk menganalisis hubungan sebab akibat antara variabel independen dengan variabel dependen (Hartono 2011, 12). Jenis data yang digunakan dalam penelitian ini adalah data kuantitatif berupa laporan keuangan perusahaan sub sektor makanan dan minuman yang tercatat dalam Bursa Efek Indonesia periode 2014-2020. Sumber data yang digunakan adalah data sekunder sebagai data utama yang didapat secara tidak langsung dan telah dipublikasikan dalam www.idx.co.id ataupun website resmi dari masing-masing perusahaan.

Populasi merupakan keseluruhan objek yang karakteristiknya akan diuji (Suliyanto 2016, 43). Dalam penelitian ini populasi yang digunakan adalah seluruh perusahaan sektor industri makanan dan minuman yang terdaftar di BEI yang berjumlah 26 perusahaan. Sampel menurut Suliyanto (2016, 43), adalah sebagian populasi yang karakteristiknya akan diuji. Penelitian ini menggunakan teknik pengambilan sampel non probabilitas, purposive sampling dengan kriteria 
tertentu sebagai batasan, diantaranya adalah perusahaan menerbitkan laporan keuangan secara rutin mulai dari tahun 2014-2020, periode penerbitan tersebut tidak didapat kerugian dalam kegiatan operasional perusahaan. Berdasarkan kriteria tersebut didapat sampel sebanyak 12 perusahaan dan 84 laporan keuangan. Adapun perusahaan yang tertera pada Tabel 1 adalah sebagai sampel, dimana data yang diambil adalah volume penjualan, biaya produksi, dan pajak penghasilan dari laporan keuangan masing-masing perusahaan, sehingga menghasilkan sampel sebanyak 84 data yang berasal dari 12 perusahaan pada periode 7 tahun. Analisis data menggunakan model regresi dengan bantuan perangkat lunak SPSS.

Tabel 1. Sampel Penelitian

\begin{tabular}{|c|c|c|}
\hline No. & $\begin{array}{c}\text { Kode } \\
\text { Perusahaan } \\
\end{array}$ & Nama Perusahaan \\
\hline 1 & ALTO & Tri Banyan Tirta Tbk \\
\hline 2 & CEKA & Wilmar Cahaya Indonesia Tbk. \\
\hline 3 & DLTA & Delta Djakarta Tbk. \\
\hline 4 & ICBP & Indofood CBP Sukses Makmur Tbk. \\
\hline 5 & INDF & Indofood Sukses Makmur Tbk. \\
\hline 6 & MLBI & Multi Bintang Indonesia Tbk. \\
\hline 7 & MYOR & Mayora Indah Tbk. \\
\hline 8 & ROTI & Nippon Indosari Corpindo Tbk. \\
\hline 9 & SKBM & Sekar Bumi Tbk. \\
\hline 10 & SKLT & Sekar Laut Tbk. \\
\hline 11 & STTP & Siantar Top Tbk. \\
\hline 12 & ULTJ & Ultrajaya Milk Industry Tbk. \\
\hline
\end{tabular}

\section{HASIL DAN PEMBAHASAN PENELITIAN}

\section{Hasil Uji Normalitas}

Tabel 2. Hasil Uji Normalitas

\begin{tabular}{llcccc}
\hline & & $\begin{array}{c}\text { Volume } \\
\text { Penjualan }\end{array}$ & $\begin{array}{c}\text { Biaya } \\
\text { Produksi }\end{array}$ & Pajak & Laba Bersih \\
\hline $\boldsymbol{N}$ & & 84 & 84 & 84 & 84 \\
Normal & Mean & 2782275,25 & 2101931,19 & 190324,43 & 1145115,10 \\
Parameters $^{a, b}$ & Std. Deviation & 446902,756 & 276740,811 & 44791,678 & 393361,607 \\
Most Extreme & Absolute & 0,100 & 0,054 & 0,100 & 0,102 \\
Differences & Positive & 0,100 & 0,054 & 0,100 & 0,102 \\
& Negative & $-0,061$ & $-0,052$ & $-0,056$ & $-0,085$ \\
Test Statistic & & 0,100 & 0,054 & 0,100 & 0,102 \\
Asymp. Sig. (2-tailed) & 0,071 & 0,200 & 0,072 & 0,060 \\
\hline Sumber: data sekunder(diolah) & \multicolumn{4}{c}{}
\end{tabular}

Tabel 2 menyajikan hasil perhitungan nilai $\mathrm{Z}$ dengan menggunakan Kolmogorov-Smirnov dimana terdapat nilai Asymp. Sig. (2-tailed) dari nilai Z tersebut. Nilai Asymp. Sig. (2-tailed) untuk seluruh variabel masing-masing adalah $0,71,0,2,0,72$, dan 0,6. Seluruh nilai tersebut lebih besar dari 0,05, dengan demikian, data residual seluruh variabel dalam penelitian ini telah terdistribusi secara normal. 


\section{Hasil Uji Multikolinearitas}

Tabel 3. Hasil Uji Multikolinearitas

\begin{tabular}{lcc}
\hline \multicolumn{1}{c}{ Model } & Tolerance & VIF \\
\hline Volume Penjualan & 0,865 & 1,155 \\
Biaya Produksi & 0,721 & 1,388 \\
Pajak & 0,822 & 1,217 \\
\hline \multicolumn{2}{l}{ Sumber: data sekunder (diolah) }
\end{tabular}

Hasil dari uji multikolinearitas pada Tabel 3 menunjukkan bahwa setiap variabel independen memiliki nilai Tolerance > 0,1 dan nilai Variance Inflation Factor $(V I F)<10$. Oleh karena itu, dapat dikatakan bahwa tidak ada multikolinearitas variabel independen pada model regresi.

\section{Hasil Uji Autokorelasi}

Tabel 4. Hasil Uji Autokorelasi

\begin{tabular}{cccccc}
\hline Model & $\boldsymbol{R}$ & $\boldsymbol{R}$ Square & $\begin{array}{c}\text { Adjusted } \boldsymbol{R} \\
\text { Square }\end{array}$ & $\begin{array}{c}\text { Std. Error of } \\
\text { the Estimate }\end{array}$ & $\begin{array}{c}\text { Durbin- } \\
\text { Watson }\end{array}$ \\
\hline 1 & 0,410 & 0,168 & 0,131 & 368255,409 & 1,809 \\
\hline Sumber: data sekunder (diolah) & & &
\end{tabular}

Tabel 3 memperlihatkan nilai statistik Durbin Watson sebesar 1,809. Selanjutnya nilai tersebut akan dibandingkan dengan tabel kriteria pengambilan keputusan. Nilai dU sebesar 1,997 dan nilai 3-dU sebesar 1,003. Karena nilai Durbin Watson 1,809 berada diantara dU dan 3-DU, sehingga tidak terdapat autokorelasi.

\section{Hasil Uji Heteroskedastisitas}

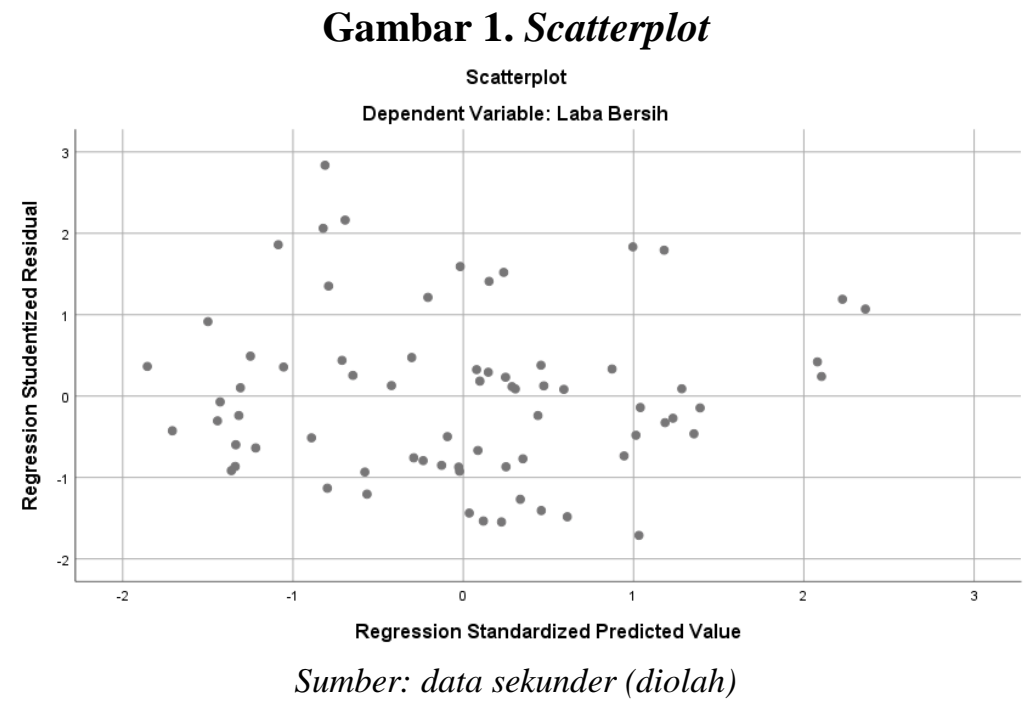

Gambar 1 merupakan hasil scatterplot untuk uji heteroskedastisitas, dalam gambar tersebut terdapat titik-titik yang menyebar dan tidak ada yang menumpuk 
antara yang satu dengan yang lainnya. Hal ini berarti bahwa penelitian lolos uji heteroskedastisitas.

\section{Hasil Uji Hipotesis}

Tabel 5. Hasil Estimasi Model

\begin{tabular}{lcccc}
\hline \multirow{1}{*}{ Model } & \multicolumn{2}{c}{$\begin{array}{c}\text { Unstandardized } \\
\text { Coefficients }\end{array}$} & \multirow{t}{*}{} & \multirow{2}{*}{ Sig. } \\
\cline { 2 - 3 } & $\boldsymbol{B}$ & Std. Error & & \\
\hline (Constant) & 281401,430 & 378226,896 & 0,744 & 0,459 \\
Volume Penjualan & $-0,024$ & 0,105 & $-0,230$ & 0,819 \\
Biaya Produksi & 0,166 & 0,187 & 0,892 & 0,375 \\
Pajak & 3,072 & 1,078 & 2,851 & 0,006 \\
\hline
\end{tabular}

Sumber: data sekunder (diolah)

Tabel 5 memperlihatkan hasil estimasi model penelitian untuk masingmasing variabel. Diketahui bahwa $t_{\text {tabel }}$ adalah 1,995 dan a sebesar 5\% $(0,05)$. Untuk variabel volume penjualan diketahui nilai sig. 0,819 lebih besar dari a $(0,05)$ dan $t_{\text {hitung }}$ sebesar $-0,230$ lebih kecil dari $t_{\text {tabel }}$ sebesar 1,995 , sehingga $\mathrm{H}_{1}$ ditolak, artinya volume penjualan tidak berpengaruh terhadap laba bersih. Untuk variabel biaya produksi nilai sig. sebesar 0,375 lebih besar dari a $(0,05)$ dan $t_{\text {hitung }}$ sebesar 0,892 lebih kecil dari $\mathrm{t}_{\text {tabel }}$ sebesar 1,995, sehingga $\mathrm{H}_{2}$ ditolak, artinya biaya produksi tidak berpengaruh terhadap laba bersih. Untuk variabel pajak, diketahui nilai sig. sebesar 0,006 lebih kecil dari a $(0,05)$ dan $t_{\text {hitung }}$ sebesar 2,851 lebih besar dari $t_{\text {tabel }}$ sebesar 1,997 , sehingga $\mathrm{H}_{3}$ diterima, artinya pajak berpengaruh terhadap laba bersih perusahaan.

Tabel 6. Uji F Simultan

\begin{tabular}{lccc}
\hline \multicolumn{1}{c}{ Model } & $\boldsymbol{d} \boldsymbol{f}$ & $\boldsymbol{F}$ & Sig. \\
\hline Regression & 3 & 4,509 & 0,006 \\
Residual & 67 & & \\
Total & 70 & & \\
Sumber: data sekunder (diolah)
\end{tabular}

Tabel 6 menjelaskan uji $\mathrm{F}$ menggunakan anova, didapatkan nilai $\mathrm{F}_{\text {hitung }}$ sebesar 4,509 dan nilai sig. sebesar 0,006. Dengan membandingkan $F_{\text {hitung }}$ dan $F_{\text {tabel }}$ sebesar 2,70 maka $F_{\text {hitung }}$ lebih besar dari $F_{\text {tabel, }}$, kemudian nilai sig. lebih kecil dari 0,05 . Hal ini berarti secara simultan volume penjualan, biaya produksi dan pajak berpengaruh signifikan terhadap laba bersih perusahaan.

\section{Pengaruh Volume Penjualan Terhadap Laba Bersih}

Hasil penelitian ini menunjukkan bahwa $\mathrm{H}_{1}$ ditolak, berarti volume penjualan tidak berpengaruh terhadap laba bersih perusahaan. Penyebab dari hal tersebut diduga karena perusahaan sektor makanan dan minuman yang menjadi sampel penelitian memiliki cabang unit usaha lain diluar bisnis utama sehingga volume penjualan makanan dan minuman tidak berpengaruh terhadap laba yang dihasilkan. Hasil penelitian ini sejalan dengan penelitian yang dilakukan oleh Nastiti (2019); Diana, Fani, Bangun, and Saragi (2021) yang menyatakan bahwa 
hasil volume penjualan tidak berpengaruh terhadap laba bersih. Hasil penelitian ini tidak sejalan dengan teori dari Mulyadi $(2014,303)$ dan penelitian yang dilakukan oleh Alam (2020); Fitrasani (2019); Lisna and Hambali (2020); Puspitasari (2017) yang menyatakan bahwa hasil volume penjualan berpengaruh terhadap laba bersih.

\section{Pengaruh Biaya Produksi Terhadap Laba Bersih}

Hasil penelitian ini menunjukkan bahwa $\mathrm{H}_{2}$ ditolak, berarti biaya produksi tidak berpengaruh terhadap laba bersih perusahaan. Terjadinya hasil yang tidak sesuai dikarenakan peneliti hanya menggunakan komponen biaya produksi sebagai variabel. Tidak menggunakan komponen biaya lain yaitu biaya komersial yang terdiri dari biaya penjualan dan administrasi/umum. Sehingga komponen biaya yang diteliti ini hanya sebagian dari total biaya yang ada dalam perusahaan. Hasil penelitian ini sejalan dengan penelitian yang dilakukan oleh Casmadi and Butar (2018); Novialita and Ritonga (2019) yang menyatakan bahwa biaya produksi tidak berpengaruh terhadap laba bersih perusahaan. Hasil penelitian ini tidak sejalan dengan teori Mulyadi $(2014,303)$ dan penelitian yang dilakukan Suwarni (2018); Jawad (2018); Izmi (2019); Ambarwati and Kusnadianti (2021) yang menyatakan bahwa biaya produksi berpengaruh terhadap laba bersih.

\section{Pengaruh Pajak Penghasilan Terhadap Laba Bersih}

Hasil penelitian ini menunjukkan bahwa $\mathrm{H}_{3}$ diterima, berarti pajak penghasilan berpengaruh terhadap laba bersih. Hasil ini sejalan dengan teori dari Mardiasmo (2016, 3) dan penelitian yang dilakukan oleh Handayani (2017); Wahyuni (2017); Purdiansyah and Nurasik (2018) yang dilakukan oleh Nur et al. (2019) yang menyatakan bahwa pajak penghasilan berpengaruh terhadap laba bersih. Pajak merupakan kewajiban dari perusahaan yang sudah memperoleh laba. Dengan adanya pembayaran pajak maka laba bersih perusahaan jelas akan mengalami penurunan, berapapun beban pajak yang ditanggung perusahaan.

\section{Pengaruh Volume Penjualan, Biaya Produksi, Dan Pajak Penghasilan Terhadap Laba Bersih}

Hasil uji penelitian yang dilakukan secara simultan menunjukkan hasil bahwa volume penjualan, biaya produksi, dan pajak penghasilan secara bersamasama berpengaruh signifikan terhadap laba bersih. Hal ini sejalan dengan penelitian yang dilakukan oleh Handayani (2017); Wahyuni (2017); Purdiansyah and Nurasik (2017); Gita (2017); Fitrasani (2019); Nur et al. (2019); Alam (2020); Lisna and Hambali (2020).

\section{KESIMPULAN}

Secara parsial ternyata pajak penghasilan berpengaruh terhadap laba bersih perusahaan. Sedangkan secara parsial volume penjualan dan biaya produksi tidak berpengaruh terhadap laba bersih perusahaan. Kemudian Secara simultan volume penjualan, biaya produksi, dan pajak berpengaruh signifikan terhadap laba bersih perusahaan.

Penelitian ini dilakukan di sektor makanan dan minuman oleh karena itu hasil penelitian dapat dijadikan referensi bagi investor dalam memilih perusahaan 
makanan dan minuman. Kemudian hasil penelitian ini dapat juga menjadi referensi bagi perusahaan dalam meningkatkan laba. Penelitian ini memiliki keterbatasan dalam hal cakupan, aspek, dan periode penelitian.

Diharapkan penelitian selanjutnya dapat memperluas scope penelitian agar hasil yang diperoleh dapat lebih general dan dipergunakan untuk semua sektor usaha. Kemudian dapat menambah variabel penelitian seperti beban penjualan, beban operasional, administrasi dan umum, biaya keuangan, dan sebagainya. Selanjutnya dapat menambah tahun penelitian dengan maksud agar hasil lebih valid.

\section{DAFTAR PUSTAKA}

Alam, Paku. 2020. Pengaruh Volume Penjualan Dan Biaya Operasional Terhadap Laba Bersih Pada Perusahaan Food And Beverage Yang Terdaftar Di Bursa Efek Indonesia. Skripsi Universitas Tridinanti Palembang. http://repository.univ-tridinanti.ac.id/1971/.

Ambarwati, Dita, and Yanthi Kusnadianti. 2021. "Pengaruh Penjualan Terhadap Laba Bersih Pada Primer Koperasi Kartika Kijang Cakti Periode 20162020.” Jurnal Ilmiah Manajemen, Ekonomi, dan Akuntansi (MEA), 5(3): 214-227.

http://www.journal.stiemb.ac.id/index.php/mea/article/view/1424.

Casmadi, Yohanes, and Fransiska Sri Rejeki Butar Butar. 2018. "Pengaruh Biaya Produksi Dan Penjualan Terhadap Laba Bersih (Studi Kasus Pada Perusahaan Manufaktur Yang Terdaftar Di Bursa Efek Indonesia Sub Sektor Kabel Periode 2013-2017).” Jurnal Akuntansi, 10(2): 14-26. https://ejurnal.poltekpos.ac.id/index.php/akuntansi/article/view/804/.

Diana, Diana, Julkenti Fani, Stefani Bangun, and Erawati Saragi. 2021. "Pengaruh Utang, Modal Kerja, Dan Penjualan Terhadap Laba Bersih Pada Sektor Food And Beverage Yang Terdaftar Di Bursa Efek Indonesia Periode Tahun 2014-2018." Jurnal Manajemen, 7(1): 25-42. http://ejournal.lmiimedan.net/index.php/jm/article/view/127.

Diana, Diana, Novia Novia, Devianti Sagala, Steven Steven, and Anggelin Mahesi Djokri. 2020. "Pengaruh Biaya Operasional, Biaya Produksi, Dan Penjualan Terhadap Laba Bersih Pada Perusahaan Manufaktur Sektor Dasar Industri Dan Kimia Yang Terdaftar Di Bursa Efek Indonesia Periode 2015-2019." Jurnal Ilmu Manajemen Methonomix, 3(2): 71-80. http://methonomi.net/index.php/jm/article/view/143.

Firmansyah, Jabar. 2019. Analisis Faktor-Faktor Yang Mempengaruhi Laba Bersih, Perubahan Pendapatan Dan Beban Pada PT. Alumindo Light Metal Industry Tbk. Skripsi Universitas Muhammadiyah Palembang. http://repository.um-palembang.ac.id/id/eprint/5640/.

Fitrasani, Anisa Nuzul. 2019. Analisis Pengaruh Biaya Produksi, Biaya Operasional, Dan Volume Penjualan Terhadap Laba Bersih Pada Perusahaan Manufaktur Yang Terdaftar Di Bursa Efek Indonesia Periode 2013-2016. Skripsi Sekolah Tinggi Ilmu Ekonomi Yayasan Keluarga Pahlawan Negara Yogyakarta. http://repository.stieykpn.ac.id/67/. 
Ghozali, Imam, and Anis Cahariri. 2014. Teori Akuntansi International Financial Reporting. Semarang: Badan Penerbit Universitas Diponegoro.

Handayani, Fitri. 2017. Analisis Pengaruh Penjualan, Pajak Penghasilan, Dan Biaya Opersional Terhadap Laba Bersih PT. Alam Sutera Realty Tbk. Skripsi Institut Agama Islam Negeri Padangsidempuan. http://etd.iainpadangsidimpuan.ac.id/4130/.

Hartono, Jogiyanto. 2011. Metode Penelitian Bisnis: Salah Kaprah Dan Pengalaman-Pengalaman. Yogyakarta: BPFE.

Islahuzzaman, Islahuzzaman. 2012. Istilah-Istilah Akuntansi dan Auditing. Jakarta: Bumi Aksara.

Izmi, Fira Nurul. 2019. Pengaruh Beban Pokok Penjualan Terhadap Laba Bersih Pada Perusahaan Manufaktur Yang Terdaftar Di Bursa Efek Indonesia. Skripsi Universitas Muhammadiyah Sumatera Utara. http://repository.umsu.ac.id/handle/123456789/5964.

Jawad, Naufal Abdul. 2018. "Pengaruh Modal Kerja Dan Volume Penjualan Terhadap Laba Perusahaan." Jurnal Akuntansi Universitas Muhammadiyah Palopo, 67-80. https://journal.stiem.ac.id/index.php/jurakun/article/view/519.

Kasmir, Kasmir. 2011. Analisis Laporan Keuangan, edisi 1 cetakan 4. Jakarta: Grafindo Persada.

Lisna, Taradiva, and Denny Hambali. 2020. "Pengaruh Biaya Produksi, Harga Jual dan Volume Penjualan Terhadap Laba Bersih (Studi Kasus Perusahaan Pertambangan Batubara yang Terdaftar di Bursa Efek Indonesia Periode 2014-2017)." Jurnal Ekonomi dan Bisnis Indonesia (JEBI), 5(2): 41-49. http://jurnal.uts.ac.id/index.php/jebi/article/view/854.

Mardiasmo, Mardiasmo. 2016. Perpajakan, edisi revisi. Yogyakarta: Andi.

Mulyadi, Mulyadi. 2014. Akuntansi Biaya, edisi 5. Yogyakarta: Universitas Gajah Mada.

Mulyadi, Mulyadi. 2015. Sistem Informasi Akuntansi. Jakarta: Salemba Empat.

Nastiti, Gema Ade Lupita. 2019. Pengaruh Biaya Produksi, Volume Penjualan Terhadap Laba Bersih Perusahaan (Study Pada CV. Tunik Putri, Surabaya). Skripsi Universitas Bhayangkara Surabaya. http://eprints.ubhara.ac.id/576/.

Nur, Fahmi, Nur Pitriani, Puji Haryanti, Rifkiana Nur C., Toni Ardiansyah, and Suripto Suripto. 2019. "Pengaruh Pendapatan Usaha, Biaya Operasional, Volume Penjualan, Dan Pajak Penghasilan Terhadap Laba Bersih." Prosiding Webinar Nasional: "Covid-19 Pandemic and current Issue in Accounting Research”, Program Studi Sarjana Akuntansi Universitas Pamulang.

http://openjournal.unpam.ac.id/index.php/Proceedings/article/view/9911.

Novialita, Wulan and Ferdiansyah Ritonga. 2019. "Pengaruh Penjualan Dan Biaya Produksi Terhadap Laba Bersih (Perusahaan Manufaktur Yang Terdapat Di Bursa Efek Indonesia Periode Tahun 2014-2018)." Jurnal Sains Manajemen \& Akuntansi, 1-28.

Purdiansyah, Andi, and Nurasik Nurasik. 2018. "Pengaruh Biaya Operasional Dan Beban Pajak Terhadap Kemampuan Laba Bersih Dengan Persediaan Sebagai Variabel Moderasi Perusahaan Makanan Dan Minuman Yang Terdaftar Di Bursa Efek Indonesia Periode 2014-2016." Indonesian 
Journal of Law and Economics Review, 1(2): 1-12 . https://doi.org/10.21070/ijler.v1i2.3106.

Puspitasari, Gita. 2017. "Pengaruh Modal Kerja Dan Penjualan Terhadap Laba

Bersih Pada Perusahaan Food And Beverage Yang Terdaftar Di Bursa

Efek Infdonesia Periode 2011-2015". Jurnal Manajemen dan Bisnis

(ALMANA):

100-112.

http://journalfeb.unla.ac.id/index.php/almana/article/view/367.

Suliyanto, Suliyanto. 2016. Metode Riset Bisnis. Yogyakarta: Andi.

Suwarni, Husaimah. 2018. Pengaruh Penjualan, Perputaran Piutang, Dan Modal Kerja Terhadap Laba Bersih (Studi Kasus Perusahaan Sub Sektor Farmasi yang Terdaftar di ISSI Periode 2011-2016). Skripsi Universitas Islam Negeri Raden Fatah Palembang. http://repository.radenfatah.ac.id/9799/.

Wahyuni, Sri. 2019. Pengaruh Penjualan, Beban Operasional, Pajak Penghasilan Terhadap Laba Bersih Pada Perusahaan Manufaktur Subsektor Bahan Kimia Yang Terdaftar Di Bursa Efek Indonesia. Skripsi Universitas Pembangunan Pasca Budi Medan. https://jurnal.pancabudi.ac.id/index.php/jurnalfasosa/article/view/3322. 